\title{
Deskripsi Hasil Perkuliahan Mahasiswa Program Studi Pendidikan Biologi S1 Universitas Muhammadiyah Metro
}

\author{
Hening Widowati \\ Dosen Pendidikan Biologi Jurusan Pendidikan MIPA \\ FKIP Universitas Muhammadiyah Metro \\ surat elektronik: hwummetro@gmail.com
}

\begin{abstract}
ABSTRAK
Penelitian deskriptif ini dilakukan pada program studi Pendidikan Biologi pada semester ganjil dan genap 2013/20I4, melalui studi dokumentasi terhadap entry pemaketan mata kuliah yang terdata dalam KRS (Kartu Rencana Studi), serta KHS/Kartu Hasil Studi mahasiswa. Diperoleh rerata paket matakuliah maksimal/24 sks semester ganjil dan genap berhasil diprogramkan oleh $\geq 90 \%$ mahasiswa, dengan perolehan IP rerata $\geq 90 \%$ mahasiswa adalah $\geq 3,0$. Capaian hasil belajar secara umum mengalami penurunan. Pada nilai A menurun 4,67\%, A- menurun 6,75\%, B+ menurun I,9\%. Di sisi lain terjadi kenaikan prosentase mahasiswa yang mendapatkan nilai di bawah KKM, yaitu terjadi peningkatan jumlah mahasiswa yang mendapatkan nilai di bawah B termasuk nilai yang belum lulus karena permasalahan mahasiswa tertentu dengan peningkatan hampir I00\%. Kondisi ini memperkuat kesimpulan terjadinya penurunan hasil perkuliahan secara keseluruhan.
\end{abstract}

Kata kunci: hasil perkuliahan semester ganjil dan genap, program studi pendidikan biologi tahun akademik $2013 / 2014$

\section{Pendahuluan}

Buku Pedoman Akademik Universitas Muhammadiyah Metro Bab II Pendidikan Pasal 2 Landasan Program Pendidikan ayat 9 tentang hakekat dosen (2006) menyatakan, bahwa dalam kegiatan akademik di perguruan tinggi, dosen merupakan agen pembaharuan yang berperan memimpin dan mendukung nilai masyarakat, memahami karakteristik unik dan berupaya memenuhi kebutuhan pendidikan dan masingmasing peserta didik/mahasiswa yang memiliki minat dan potensi yang perlu diwujudkan secara optimal. Sebagai fasilitator pembelajaran, dosen menciptakan kondisi yang menggugah dan menyediakan kemudahan bagi mahasiswa untuk belajar. Pendidik tenaga pendidikan dituntut menjadi contoh dalam pengelolaan proses belajar mengajar bagi calon guru yang menjadi subjek didiknya; dosen bertanggungjawab secara professional dan terus menerus meningkatkan kemampuannya,serta menjunjung tinggi kode etik profesional.

Selanjutnya Buku Pedoman Akademik UM Metro Bab II Pasal 2 Landasan Program Pendidikan ayat I0 tentang hakekat belajar mengajar menandaskan bahwa peristiwa belajar mengajar di perguruan tinggi Universitas Muhammadiyah Metro terjadi apabila mahasiswa secara aktif berinteraksi dengan lingkungan belajar yang diatur oleh dosen. Di dalam interaksi belajar mengajar tersebut, setiap mahasiswa diperlakukan sebagai manusia bermartabat, yang minat dan potensinya perlu diwujudkan secara optimal. Proses belajar mengajar yang efektif memerlukan strategi dan media/teknologi pendidikan yang tepat, proses belajar mengajar dirancang dan dilakukan sebagai sistem, proses dan produk belajar perlu memperoleh perhatian seimbang di dalam pelaksanaan kegiatan belajar mengajar. Pembentukan kemampuan profesional memerlukan pengintegrasian fungsional antara teori dan praktek serta materi dan metodologi penyampaiannya. Pembentukan kemampuan profesional memerlukan pengalaman lapangan yang bertambah serta sistematis, mulai dari pengenalan medan, latihan keterampilan terbatas sampai dengan pelaksanaan dan penghayatan tugas-tugas serta utuh dan aktual. Kriteria keberhasilan yang utama dalam pendidikan profesional adalah peragaan penguasaan kemampuan melalui unjuk kerja; serta materi belajar dan sistem penyampaian yang berkembang.

Didasarkan pada pasal 2 Landasan Program Pendidikan yang tertuang dalam masing-masing ayat berkaitan hakekat pendidikan dan hakekat proses pembelajarannya, diharapkan tujuan umum program 
pendidikan sebagaimana tertuang pada pasal 3 yaitu meningkatkan peserta program melalui pengalaman belajar untuk menghasilkan lulusan yang memiliki penguasaan perangkat kemampuan yang meliputi kesadaran dan kemampuan kemampuan diri, penguasaan bidang ilmu, penguasaan prinsip dasar kinerja dan kemampuan menyusun dan menyelenggarakan tugastugas lainnya dapat dicapai.

Buku Pedoman Akademik UM Metro Bab II Pasal 6 tentang penyelenggaraan pendidikan, administrasi akademik di Universitas Muhammadiyah Metro diselenggarakan dengan menerapkan Satuan Kredit Semester (SKS). Penyelenggaraan pendidikan dilaksanakan melalui kuliah dan ditunjang dengan praktikum, responsi, latihan, diskusi, seminar, kuliah kerja, simulasi, penelitian, dan kegiatan ilmiah lainnya. Bahasa pengantar kegiatan akademik lisan dan tulisan adalah bahasa Indonesia yang baku. Kegiatan penunjang dinyatakan dalam kurikulum atau dalam program jurusan/fakultas, dilaksanakan dalam periode perkuliahan dan merupakan salah satu komponen penilaian akhir. Pendidikan dilaksanakan oleh fakultas, jurusan, atau laboratorium. Tahun akademik penyelenggaraan pendidikan terdiri atas dua semester; semester ganjil adalah Agustus-Januari; dan semester genap Februari-Juli.

Buku Pedoman Akademik UM Metro Bab II Pasal 9 menyatakan, dalam menjalani studi, setiap mahasiswa Universitas Muhammadiyah Metro didampingi oleh seorang Dosen PA (Pembimbing Akademik) yang membantu menyusun KRS, memberi pertimbangan pengambilan matakuliah, banyaknya kredit yang diambil sesuai keberhasilan studi pada semester sebelumnya, mengikuti, mengamati, dan perkembangan studi mahasiswa yang dibimbingnya secara berkala, serta mencatat dan mengevaluasi program yang dijalani mahasiswa dengan tata cara yang diberlakukan di Universitas Muhammadiyah Metro. Dosen PA berwenang memberi nasehat, membantu memecahkan masalah yang menghambat kelancaran studi mahasiswa, membantu mengatasi kesukaran-kesukaran, serta meneruskan permasalahan mahasiswa yang bukan wewenangnya kepada yang berwenang untuk menangani masalah tersebut. Dalam pasal I0 dinyatakan, di dalam menangani masalah-masalah yang di luar kemampuan Dosen PA atau terlalu jauh dari masalah akademik, pelaksanaan bimbingan diserahkan kepada kelompok penasehat mahasiswa, yang terdiri atas dosen-dosen yang memahami persyaratan mempunyai keahlian dalam bidang konseling.

Buku Pedoman Akademik UM Metro Bab II Pendidikan Pasal 12 tentang Beban Studi Semester, bahwa beban studi semester I dan II hanya mata kulaih wajib semester I dan II yaitu I8-20 sks. Setelah semester II ditentukan oleh keberhasilan studi semester sebelumnya yang dinyatakan dengan Indeks Prestasi (IP). IP semester lalu $>3,00$ maka batas maksimal kisaran beban studi semester berikutnya adalah 2I-24 sks; IP 2,5-2,99 yaitu I8-2I sks; IP 2,0-2,49 yaitu I5I8 sks; I,5-I,99 yaitu I2-I5 sks; <-I,49 yaitu I2 sks.

Buku Pedoman Akademik UM Metro Bab II Pendidikan Pasal I3 menyatakan mata kuliah yang berhuruf mutu E harus diulang. Mata kuliah yang berhuruf $\mathrm{D}$ dapat diambil ulang. Pengambilan ulang mata kuliah hanya dapat dilakukan dalam periode studi I4 semester, nilai yang akan direkam adalah nilai tertinggi.

Buku Pedoman Akademik UM Metro Bab II Pendidikan Pasal I4 menyatakan penilaian hasil belajar dilakukan secara berkala dalam bentuk ujian, pelaksanaan tugas, dan pengamatan oleh dosen. Penyelenggaraan penilaian dapat melalui mid semester, praktikum, ujian semester secara tertulis; ujian skripsi secara lisan; berkas ujian dan berbagai berkas tertulis yang mendapatkan penilaian harus dikembalikan kepada mahasiswa; penilaian pendidikan dinyatakan dengan huruf mutu A (7,95-I0,0), A- (7,65-7,94), B+ (7,25$7,64)$, B (6,85-7,24), B- $(6,45-6,84)$, C+ (6,05-6,44), C $(5,65-6,04)$, C- $(5,25-5,64)$, D $(4,85-5,24)$, E $(<4,85)$; berdasarkan Penilaian Acuan Patokan (PAP).

Dalam suatu pembelajaran apapun, diharapkan dengan proses yang selalu dan semakin diperbaiki ada peningkatan hasil belajar. Seperti diungkapkan Mukaromah (I999: 2), hasil belajar merupakan perolehan perubahan pada diri siswa yang terwujud dalam perubahan tingkah laku. Hasil belajar menurut Sujana (I99I: 22) adalah kemampuan-kemampuan yang dimiliki siswa setelah ia menerima pengalaman belajarnya. Sedangkan menurut Yulaelawati (2004: 2I), hasil belajar mencerminkan kemampuan peserta didik dalam memenuhi suatu tahapan pencapaian pengalaman belajar dalam kompetensi dasar, yang meliputi ranah kognitif, afektif, dan psikomotorik.

Mendasarkan pada ketentuan-ketentuan dalam Buku Pedoman Akademik UM Metro, dapat dirumuskan permasalahannya: Bagaimanakah deskripsi perbandingan hasil kuliah mahasiswa program studi Pendidikan Biologi pada semester ganjil dengan genap tahun akademik 2013/20I4? Didasarkan pada rumusan masalah tersebut, maka tujuan penelitian ini adalah: Memberikan kajianhasil kuliah mahasiswa program studi Pendidikan Biologi pada tahun akademik 2013/20I4 melalui penelaahan terhadap: I) Rerata sks yang ditempuh; 2) Indeks Prestasi yang dicapai; 3) Capaian nilai huruf mutu yang diperoleh pada setiap mata kuliahnya.

\section{Metode Penelitian}

Penelitian dilakukan dengan menganalisis data berupa dokumen nilai yang tertuang pada KHS (Kartu Hasil Studi) seluruh mahasiswa aktif Program Studi Pendidikan Biologi semester ganjil dan genap tahun akademik 2013/20I4 yang dikeluarkan dari Biro Administrasi Akademik dan Kemahasiswaan (BAAK) 
Universitas Muhammadiyah Metro. Penelitian dilaksanakan pada bulan September 2013-Oktober 2014. Data dianalisis secara deskriptif dengan menghitung rata-rata, dan penelaahan didasarkan pada tuntutan proses dan hasil pembelajaran di perguruan tinggi Universitas Muhammadiyah Metro sesuai Buku Pedoman Akademik Universitas Muhammadiyah Metro yang diterbitkan pada tahun 2006 dan direvisi pada tahun 2014.

\section{Hasil dan Pembahasan}

Studi dokumentasi data nilai dari 4I4 mahasiswa aktif di semester ganjil dan 389mahasiswa aktif di semester genap Pendidikan Biologi dan hasil penelusuran data dari BAAK tentang capaian Indeks Prestasi dan peluang pengambilan jumlah kredit mata kuliah semester berikutnya dapat dilihat pada Tabel I.

Tabel I. Perolehan Indeks Prestasi Mahasiswa Pendidikan Biologi Semester Ganjil dan Genap 20I3/20I4

\begin{tabular}{|c|c|c|c|c|c|c|c|}
\hline \multirow[t]{3}{*}{ No. } & \multirow[t]{3}{*}{$\begin{array}{l}\text { Mahasiswa } \\
\text { Angkatan }\end{array}$} & \multicolumn{4}{|c|}{$\begin{array}{c}\text { Capaian IP dan } \\
\text { Jumlah Mahasiswa }\end{array}$} & \multicolumn{2}{|c|}{ KKM } \\
\hline & & \multicolumn{2}{|c|}{$\geq 3,00$} & \multicolumn{2}{|c|}{$<3,00$} & \multirow{2}{*}{$\begin{array}{c}\text { ( IP } \geq 3,00,70 \%) \\
\text { Sem Ganjil }\end{array}$} & \multirow{2}{*}{$\begin{array}{l}(\mathrm{IP} \geq 3,00, \\
70 \%) \\
\text { Sem Genap }\end{array}$} \\
\hline & & Sem Ganjil & Sem Genap & Sem Ganjil & $\begin{array}{c}\text { Sem } \\
\text { Genap }\end{array}$ & & \\
\hline I. & $\begin{array}{l}\text { Angkatan } \\
\text { 20I3) }\end{array}$ & II2 & $7 \mathrm{I}$ & 5 & 39 & $\begin{array}{l}95,73 \% \\
\text { Tercapai }\end{array}$ & $\begin{array}{c}64,55 \\
\text { (Tidak tercapai) }\end{array}$ \\
\hline 2. & $\begin{array}{l}\text { Angkatan } \\
\text { 20I2) }\end{array}$ & 43 & 50 & 8 & 0 & $\begin{array}{l}84,31 \% \\
\text { Tercapai }\end{array}$ & $\begin{array}{c}\text { I00\% } \\
\text { (Tercapai) } \\
\end{array}$ \\
\hline 3. & $\begin{array}{l}\text { Angkatan } \\
\text { 20II) }\end{array}$ & 68 & 66 & 3 & 2 & $\begin{array}{l}95,77 \% \\
\text { Tercapai }\end{array}$ & $\begin{array}{c}97,06 \\
\text { (Tercapai) }\end{array}$ \\
\hline 4. & $\begin{array}{l}\text { Angkatan } \\
\text { 20I0) }\end{array}$ & I52 & 98 & 9 & 57 & $\begin{array}{l}94,41 \% \\
\text { Tercapai }\end{array}$ & $\begin{array}{c}63,23 \\
\text { (Tidak tercapai) }\end{array}$ \\
\hline 5 & $\begin{array}{l}\text { Angkatan } \\
\text { 2009) }\end{array}$ & 8 & 0 & 6 & 5 & $\begin{array}{c}57, \mathrm{I} 4 \% \\
\text { (Tidak tercapai) }\end{array}$ & $\begin{array}{c}0 \% \\
\text { (Tidak tercapai) }\end{array}$ \\
\hline 6 & $\begin{array}{l}\text { Angkatan } \\
\text { 2007) }\end{array}$ & & & & I & & $\begin{array}{c}\text { I00\% } \\
\text { (Tercapai) }\end{array}$ \\
\hline & JUMLAH & 383 & 285 & $3 \mathrm{I}$ & I04 & & \\
\hline
\end{tabular}

Analisis terhadap perolehan Indeks Prestasi mahasiswa Pendidikan Biologi Semester Ganjil dan Genap 2013/20I4 dari Tabel I menunjukkan terjadi penurunan jumlah mahasiswa yang mencapai IP $\geq 3,00$. Bahkan capaian KKM juga mengalami penurunan atau tidak mencapai KKM khususnya mahasiswa angkatan 2009, 2010, maupun 2013, sehingga peluang untuk merencanakan pengambilan sks maksimal 24 sks juga menurun tajam.
Penelusuran melalui dosen-dosen pengampu mata kuliah, kemampuannya rata-rata, keaktifan, serta motivasi belajar dalam perkuliahan secara keseluruhan dinyatakan masih tetap sama sebagaimana terjadi pada semester ganjil, bahwa Angkatan 2013 dan 2012 paling rendah. Data diperkuat dari hasil penelusuran dapat dilihat pada Tabel 2.

Tabel 2. Penilaian Kesungguhan, Motivasi Mahasiswa dan Aktivitas Perkuliahan oleh Dosen

\begin{tabular}{ccccccc}
\hline Angkatan Mahasiswa & \multicolumn{6}{c}{ Motivasi dan Aktivitas Mahasiswa } \\
\cline { 2 - 7 } & \multicolumn{2}{c}{ Kurang } & \multicolumn{2}{c}{ Cukup } & \multicolumn{2}{c}{ Tinggi } \\
\cline { 2 - 7 } & Sem & Sem & Sem & Sem & Sem & Sem \\
& Ganjil & Genap & Ganjil & Genap & Ganjil & Genap \\
\hline 2013 & I2 & I2 & 3 & 3 & 0 & 0 \\
\hline 2012 & I4 & I4 & I & I & 0 & 0 \\
\hline $201 \mathrm{I}$ & 0 & 0 & 2 & 3 & I3 & I2 \\
\hline 2010 & 9 & 8 & 4 & 4 & 2 & 3 \\
\hline 2009 & I5 & I3 & 0 & 2 & 0 & 0 \\
\hline
\end{tabular}

Didasarkan data Tabel 2, menunjukkan adanya kecenderungan aktivitas kuliah mahasiswa Angkatan 2013 dan 2012 perlu mendapatkan prioritas perhatian. Didasarkan Tabel I dan 2., ada kecenderungan, banyak/jumlahnya mahasiswa tidak menentukan kemampuan dan tingginya aktivitas perkuliahan. Belum tentu mahasiswa yang jumlahnya lebih sedikit lebih mudah dikelola dan menghasilkan perkuliahan yang lebih baik. Akan tetapi, walaupun capaian IP mahasiswa angkatan 2012 meningkat, ternyata belum diikuti dengan indikasi kenaikan motivasi, kesungguhan belajar, dan aktivitas kuliah. Kenaikan IP semester genap sangat ditunjang oleh perolehan nilai skripsi yang hampir seluruhnya mendapatkan nilai A $(97,96 \%)$, sedangkan pada mata kuliah justru sebaliknya, mengalami penurunan baik angka mutu, maupun persentase capaian KKM nya. 
Sebagaimana diketahui motivasi subjek belajar sangat mempengaruhi aktivitas belajar, yang pada akhirnya akan menentukan hasil balajar. Belajar merupakan proses untuk mencapai suatu tujuan yang berupa hasil belajar (Suprijono, 20I I). Hasil belajar dapat dikelompokkan ke dalam tiga ranah, yaitu ranah kognitif, psikomotorik, dan afektif. Dari ketiga ranah tersebut, ranah kognitif merupakan ranah yang paling dominan sering menjadi tolok ukur atas keberhasilan subjek belajar dalam proses belajar (Sudjana, 20I0).

Hasil belajar dipengaruhi oleh dua faktor, meliputi faktor internal dan eksternal pebelajar (Slameto, 2003). Faktor internal merupakan faktor yang berasal dari dalam diri pebelajar, meliputi dua aspek yaitu aspek fisiologis atau jasmani dan psikologi atau rohani. Aspek fisiologis meliputi aspek yang berhubungan dengan kondisi fisik, misalnya kesehatan (Syah, 2009). Aspek psikologi meliputi intelegensi (Hakim, 2008), sikap, bakat, minat, motivasi, dan kesiapan (Slameto, 2003). Factor eksternal merupakan factor yang berasal dari luar diri pebelajar, terdiri atas factor lingkungan social dan factor lingkungan non sosial (Syah, 2009).
Di antara faktor internal dan eksternal yang mempengaruhi hasil belajar, faktor internal lebih dominan dan menentukan 70\% hasil belajar (Clark I98I, dalam Sudjana, 2005). Beberapa factor internal penting peranannya dalam menentukan hasil belajar di antaranya intelegensi, motivasi, dan kesiapan. Fahmie (2003) dan Sulaeman (2008) menunjukkan bahwa kemampuan intelegensi berpengaruh terhadap hasil belajar. Motivasi juga diketahui berhubungan erat dengan hasil belajar, motivasi yang tinggi dapat menyebabkan tingginya hasil belajar (Broussard, 2002; Tela, 2007; Lorden, 20I I).

Hasil penelitian Arini (2008) menunjukkan bahwa motivasi lebih kuat berpengaruh terhadap hasil belajar dibandingkan intelegensi. Selain motivasi, kesiapan belajar perlu diperhatikan, karena pebelajar dengan kesiapan belajar yang baik, akan mendapatkan hasil belajar yang lebih baik (Slameto, 2003).

Untuk menelaah lebih lanjut hasil belajarnya, nilai yang diperoleh mahasiswa pada semester genap 2013/2014 dapat dilihat rekapitulasi data nilai pada Tabel 3 .

Tabel 3. Sebaran Capaian Nilai Mata Kuliah Semester Genap 20I3/20I4

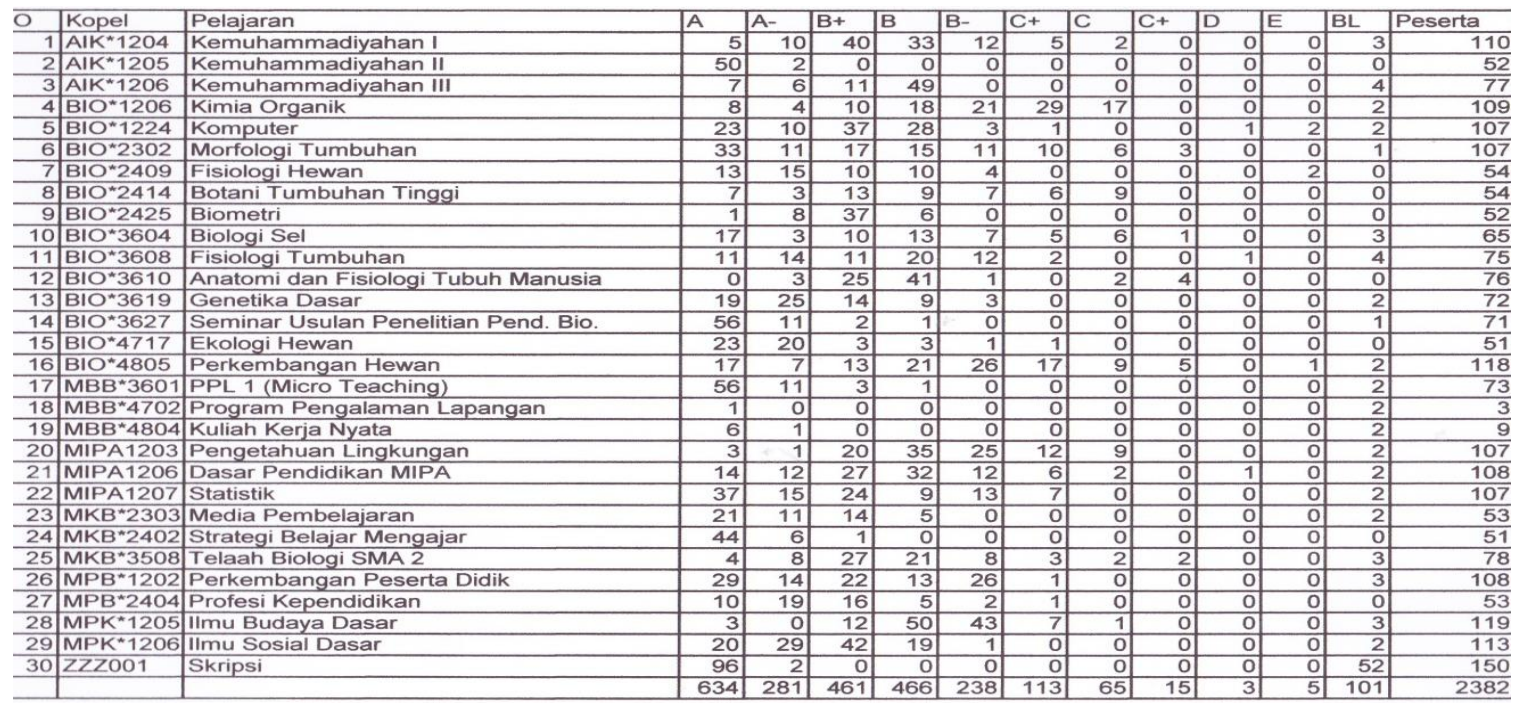

Didasarkan pada data Tabel 3, dapat diketahui bahwa mahasiswa yang mendapatkan:

- $\quad$ nilai A adalah 634/2382 X 100\% = 26,62\%;

- $\quad$ nilai A- adalah 28I $/ 2382$ X I00\% = II,8\%;

- $\quad$ nilai $\mathrm{B}+$ adalah $46 \mathrm{I} / 2382 \times 100 \%=$ I9,35\%;

- $\quad$ nilai B adalah 466/2382 X 100\% = I9,56\%;

- $\quad$ nilai B- adalah 238/2382 X 100\% = 9,99\%;

- $\quad$ nilai C+ adalah II3/2382 X I00\% = 4,74\%;
- $\quad$ nilai C adalah 65/2382 X 100\% = 2,73\%;

- $\quad$ nilai C- adalah I5/2382 X I00\% $=0,63 \%$;

- $\quad$ nilai D adalah 3/2382 X 100\% = 0,13\%;

- $\quad$ nilai E adalah 5/2382 X 100\% = 0,21\%;

- BL (Belum Lulus) adalah I0I/2382 X 100\%= $4,24 \%$.

Untuk perbandingan, pada semester ganjil diperoleh hasil, seperti tertuang pada Tabel 4.

Tabel 3. Sebaran Capaian Nilai Mata Kuliah Semester Genap 2013/20I4

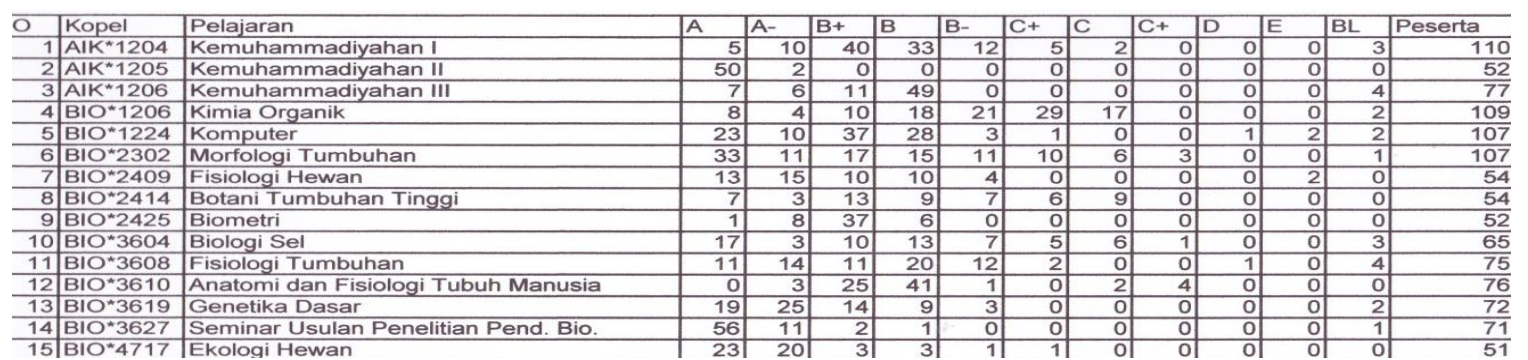




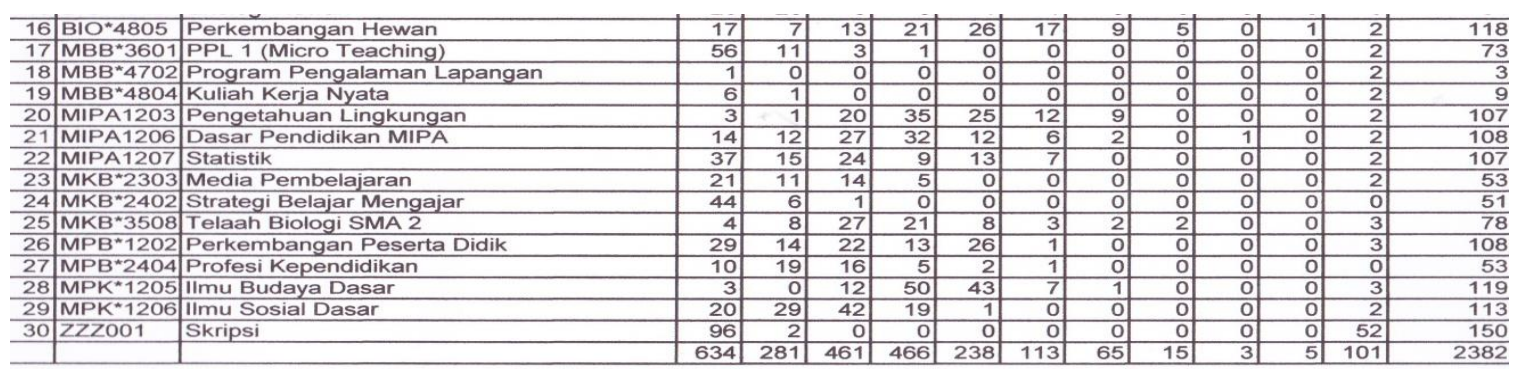

Didasarkan pada data Tabel 3, dapat diketahui bahwa mahasiswa yang mendapatkan:

- $\quad$ nilai A adalah 634/2382 X 100\% = 26,62\%;

- $\quad$ nilai A- adalah 28I/2382 X I00\% = II,8\%;

- $\quad$ nilai B+ adalah 46I/2382 X 100\% = I9,35\%;

- $\quad$ nilai B adalah 466/2382 X 100\% = 19,56\%;

- $\quad$ nilai B- adalah 238/2382 X 100\% = 9,99\%;

- $\quad$ nilai C+ adalah II3/2382 X I00\% $=4,74 \%$;
- $\quad$ nilai C adalah 65/2382 X I00\% = 2,73\%;

- $\quad$ nilai C- adalah I5/2382 X I00\% = 0,63\%;

- $\quad$ nilai D adalah $3 / 2382 \times 100 \%=0,13 \%$;

- $\quad$ nilai E adalah 5/2382 X I00\% = 0,21\%;

- BL (Belum Lulus) adalah IOI/2382 X 100\%= $4,24 \%$.

Untuk perbandingan, pada semester ganjil diperoleh hasil, seperti tertuang pada Tabel 4 .

Tabel 4. Sebaran Nilai Tiap Mata Kuliah Semester Ganjil Tahun Akademik 20I3/20I4

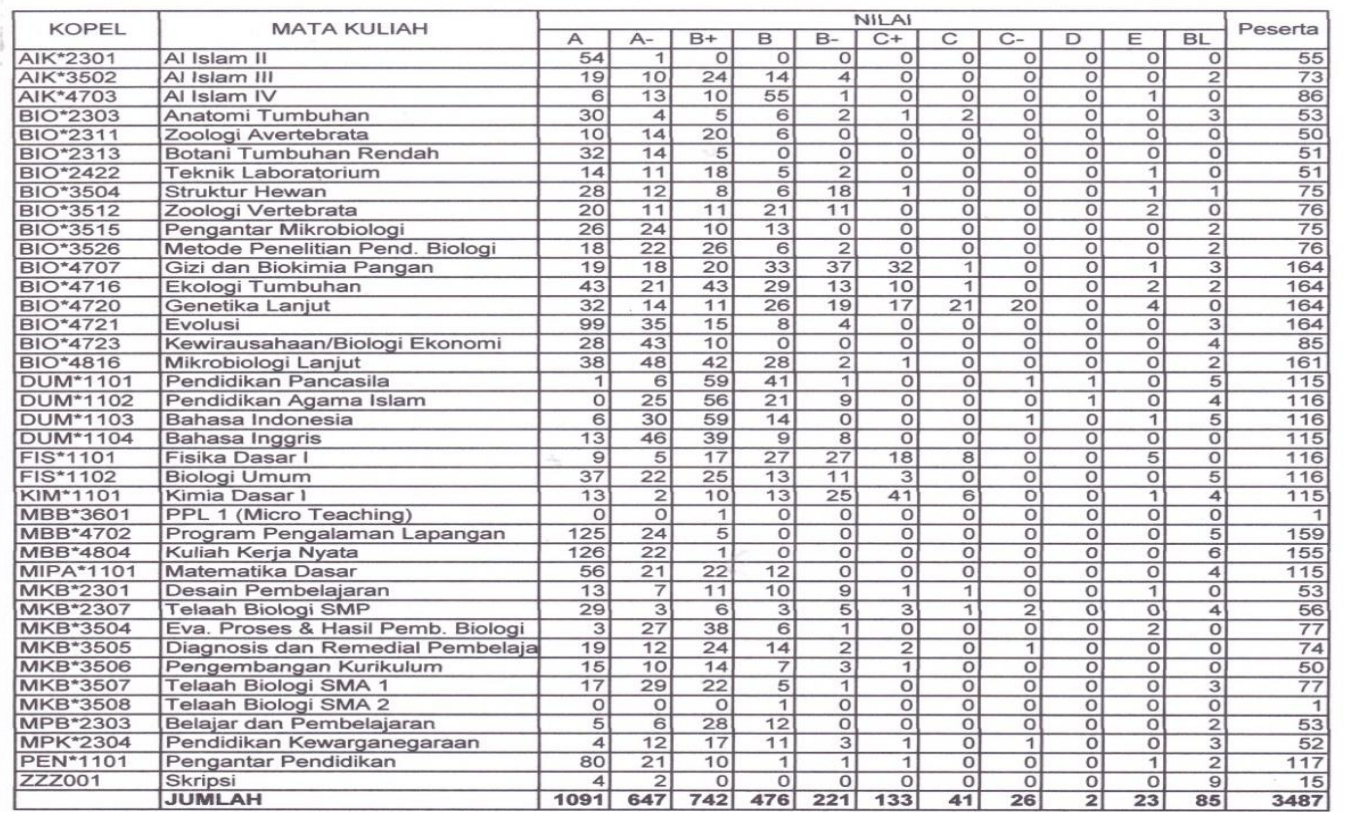

Didasarkan pada analisis Tabel 5. Dapat dijelaskan, bahwa Nilai mahasiswa pada semester genap tahun akademik 2013/2014 kategori tinggi A, A-, B+ mengalami penurunan. Sebaliknya Nilai dengan kategori rendah justru mengalami peningkatan. Kondisi ini tentu memprihatinkan. Oleh karena itu perlu memperhatikan kembali faktor-faktor lain dalam proses belajar, sehingga diharapkan hasil belajar yang dicapai dalam perkuliahan meningkat seperti yang diharapkan.

Dosen sebagai fasilitator pembelajaran bertanggungjawab atas tercapainya hasil belajar mahasiswa; menciptakan kondisi belajar kondusif; menjadi contoh dalam pengelolaan proses pembelajaran; yang secara profesional terus menerus meningkatkan kemampuannya. Proses pembelajaran dirancang dan dilakukan sebagai suatu sistem; adanya keseimbangan proses dan produk belajar; adanya pengintegrasian fungsional antara teori dan praktek; materi belajar dan sistem penyampaian yang selalu berkembang. Kegiatan akademik berpedoman pada Sistem Kredit Semester dengan mengalokasikan pada kegiatan pokok perkuliahan meliputi tatap muka, tugas terstruktur, dan tugas mandiri. Pengambilan sks mata kuliah mahasiswa didasarkan pada Indeks Prestasi semester sebelumnya. Perolehan nilai didasarkan pada partisipasi kuliah $\geq$ $80 \%$ dari yang diprogramkan, tugas, praktek, kuis, nilai Ujian Tengah Semester, nilai Ujian Akhir Semester dengan bobot dan target nilai yang ditentukan minimal B $(6,85)$ (Anonim, 2006).

\section{Simpulan}

Berdasarkan data hasil penelitian diperoleh rerata paket matakuliah maksimal/24 sks semester ganjil dan genap berhasil diprogramkan oleh $\geq 90 \%$ mahasiswa, dengan perolehan IP rerata $\geq 90 \%$ mahasiswa adalah $\geq$ 
3,0. Capaian hasil belajar secara umum mengalami penurunan. Pada nilai A menurun 4,67\%, A- menurun $6,75 \%$, B + menurun I,9\%. Di sisi lain terjadi kenaikan prosentase mahasiswa yang mendapatkan nilai di bawah KKM, yaitu terjadi peningkatan jumlah mahasiswa yang mendapatkan nilai di bawah B termasuk nilai yang belum lulus karena permasalahan mahasiswa tertentu dengan peningkatan hampir $100 \%$. Kondisi ini memperkuat kesimpulan terjadinya penurunan hasil perkuliahan secara keseluruhan.

\section{Daftar Pustaka}

Anonim. 2006. Buku Pedoman Akademik Universitas Muhammadiyah Metro. Metro: Universitas Muhammadiyah Metro.

Anonim. 2014. Buku Pedoman Akademik Universitas Muhammadiyah Metro. Edisi Revisi. Metro: Universitas Muhammadiyah Metro.

Arini, N.S. 2008. Pengaruh Tingkat Intelegensi dan Motivasi Belajar terhadap Prestasi Akademik Siswa Kelas II SMA Negeri 99 Jakarta. Laporan Penelitian. Tidak dipublikasikan, Jakarta: Universitas Gunadarma.

Broussard, S.C. 2002. The Relationship Between Classtoom Motivation and Academic Achievement in First and Third Grader. (Unpublished Tesis Lousiana State University).

Hakim, T. 2008. Belajar Secara Efektif. Jakarta: Puspa Swara.

Karwono, dan Heni Mularsih. 2012. Belajar dan Pembelajaran. Jakarta: PT Raja Grafindo Persada.

Lorden, D.H. 20II. Effects of Profesional Development Intervention on Middle School Principals to Increase Their Knowledge of and Ability to Increase Teacher Efficacy. (Unpublished disertasi San Diego State University).

Purwanto, Ngalim. 1986. Psikologi Pendidikan. Bandung: Remaja Karya.

Slameto, 2003. Belajar dan Faktor-Faktor yang Mempengaruhinya. Edisi Revisi. Jakarta: Rineka Cipta.

Sudjana, Nana, 2005. Dasar-Dasar Proses Belajar Mengajar. Bandung: Sinar Baru Algensindo.

Sudjana,Nana. 20I0. Penilaian Hasil Proses Belajar Mengajar. Bandung: PT Remaja Rosdakarya.

Suprijono, 20II. Cooperative Learning. Teori dan Aplikasi Paikem. Yogyakarta: Pustaka Pelajar.

Syah, M. 2009. Psikologi Belajar. Jakarta: PT Raja Grafindo Persada.

Tela, A. 2007. The Impact of Motivation on Student's Academic Achievement and Learning Outcomes in Mathematics Among Secondary School Student in Nigeria. Eurasia Journal of Mathematics, Science \& Technology Education, 3(2), I46-I56.

Yulaelawati, E. 2004. Kurikulum dan Pembelajaran. Jakarta: Pakar Raya. 